\title{
ITALY-2018: THE TRIUMPH OF POPULISM AND PROSPECTS OF EXIT FROM THE POLITICAL CRISIS
}

\author{
Sergey V. Biryukov \\ East China Normal University, Shanghai, China
}

\begin{abstract}
Alexander M. Barsukov
Siberian Institute of Management, Branch of the Russian Presidential Academy of National Economy and Public Administration, Novosibirsk, Russian Federation
\end{abstract}

\begin{abstract}
Introduction. The article is devoted to the origins, grounds and possible consequences of the political crisis in modern Italy. The paper shows that the Italian crisis has acquired a scale that challenges the interests of political establishment of the country and the very principles of the EU existence. Methods and materials. The authors seek a combination of General theoretical and special methods, focusing on the historical, socio-cultural and political analysis. They are based on the analysis of periodicals, as well as using articles and materials of researchers on the problems of political development in Italy. Analysis. The source of the crisis is the protest of citizens against the state authority and strategies of the political class of Italy, which is accompanied by the requirement of institutional reforms and socio-economic policy for benefit of the majority, in order to establish new political rules and form a truly legitimate political mechanism. These demands came from various social groups and led to a number of political and legal transformations, culminating in the "populist government", which came to power as a result of the parliamentary elections of 2018. The "Populist government" intended to revise many previous approaches in domestic and foreign policy. It is the Alliance of the right-wing and left-wing populists that was entrusted by Italian society with necessary reforms. Results. According to the authors, it is political populism as a possible platform for social and political transformations, along with a number of possible risks, that contains a positive potential associated with the possibility of overcoming ideological divisions, corporate selfishness of Italian politicians and parties, as well as alienation in the relations of the power and society. This approach to resolving issues by the "populist government" will contribute to the gradual resolution of the problems that have caused the long-term political crisis in Italy.
\end{abstract}

Key words: Italy, political crisis, parties, establishment, populism, reforms, sociocultural contradictions, cultural inversion.

Citation. Biryukov S.V., Barsukov A.M. Italy-2018: The Triumph of Populism and Prospects of Exit from the Political Crisis. Vestnik Volgogradskogo gosudarstvennogo universiteta. Seriya 4. Istoriya. Regionovedenie. Mezhdunarodnye otnosheniya [Science Journal of Volgograd State University. History. Area Studies. International Relations], 2019, vol. 24, no. 3, pp. 191-204. (in Russian). DOI: https://doi.org/10.15688/jvolsu4.2019.3.17

Дата поступления статьи: 30.01.2019 Дата принятия статьи: 30.04.2019

\section{ИТАЛИЯ-2018: ТОРЖЕСТВО ПОПУЛИЗМА И ПЕРСПЕКТИВЫ ВЫХОДА ИЗ ПОЛИТИЧЕСКОГО КРИЗИСА}

\author{
Сергей Владимирович Бирюков \\ Восточно-Китайский педагогический университет, г. Шанхай, Китайская Народная Республика

\section{Александр Михайлович Барсуков} \\ Сибирский институт управления - филиал Российской академии народного хозяйства \\ и государственной службы при Президенте РФ, г. Новосибирск, Российская Федерация
}


Аннотация. Статья посвящена истокам, основаниям и возможным последствиям политического кризиса в современной Италии. Анализ совокупности истоков итальянского кризиса осуществлен С.В. Бирюковым. Показано, что итальянский кризис приобрел масштабы, бросающие вызов интересам политического истеблишмента страны и самим принципам существования ЕС. Источником кризиса определен протест граждан против власти и стратегий политического класса Италии, который сопровождается требованием проведения институциональных реформ и социально-экономической политики в интересах большинства, с целью установить новые политические правила и сформировать действительно легитимные политические механизмы. Эти требования исходили от различных социальных групп и привели к целому ряду политических и правовых трансформаций, закончившись приходом к власти «правительства популистов» по итогам парламентских выборов 2018 г., намеренного пересмотреть многие прежние подходы во внутренней и внешней политике. Анализ послевыборной ситуации в Италии осуществлен А.М. Барсуковым, по заключению которого именно альянсу популистов «правого» и «левого» толка доверило итальянское общество проведение необходимых реформ. По мнению авторов, именно политический популизм в качестве возможной платформы общественно-политических преобразований, наряду с целым рядом возможных рисков, содержит в себе и позитивный потенциал, связанный с возможностью преодоления идеологических расколов, корпоративного эгоизма итальянских политиков и партий, а также отчуждения в отношениях власти и общества. Именно такой подход к решению вопросов со стороны «правительства популистов» будет способствовать постепенному разрешению проблем, ставших причиной многолетнего политического кризиса в Италии.

Ключевые слова: Италия, политический кризис, партии, истеблишмент, популизм, реформы, социокультурные противоречия, инверсия культурная.

Цитирование. Бирюков С. В., Барсуков А. М. Италия-2018: торжество популизма и перспективы выхода из политического кризиса // Вестник Волгоградского государственного университета. Серия 4, История. Регионоведение. Международные отношения. - 2019. - Т. 24, № 3. - С. 191-204. - DOI: https://doi.org/10.15688/ jvolsu4.2019.3.17

Введение. На фоне происходивших на наших глазах политических баталий во Франции и Германии ушли на второй план события в еще одной значимой стране ЕС - Италии. Между тем происходящее на Апеннинском полуострове является весьма примечательным и по-своему судьбоносным в контексте общеевропейских кризисных трендов, будь то кризис экономики и управления, проблемы с миграцией, подъем евроскептицизма или усиление популизма и национализма в рамках «еврозоны».

Италия - страна, которая постоянно изменяется, но в которой весьма сложно добиться смены действующего кабинета министров. Для любого из итальянских правительств, в свою очередь, весьма сложной задачей является доработать до окончания срока своей каденции [21]. Напомним, что начиная с 1945 г. Италия наблюдала 62 кабинета министров (при этом срок полномочий одного кабинета министров в среднем составлял 361 день) и 25 премьер-министров, каждый из которых оставил определенный след в истории страны. Общей проблемой большинства действовавших итальянских кабинетов министров была неспособность либо невозмож- ность довести до конца реформаторские начинания, которые упирались не только в политическое и общественное противодействие, но и в общее несовершенство политических институтов. Следует отметить российских исследователей Т.В. Зонову, В.Б. Кувалдина, О.Н. Барабанова, Г.Т. Сардаряна, В.П. Любина, Е.А. Маслову, С.М. Хенкина, И.С. Семененко, в научных трудах которых отражены проблемы, связанные с внутренней и внешней политикой Италии, конфликтами и особенностями политической культуры.

Между тем неудача многих проектов модернизации политической системы Италии, а равно и далеко не бесспорная эффективность итальянской модели партийной системы, заставляет задуматься о самой возможности успешно преобразовать итальянские общество, экономику и политику. Успешно решить эту задачу оказалось не под силу ни представителям партийного истеблишмента, ни пришедшим во власть либеральным технократам, ни заявлявшим о себе ранее политикам-популистам. Последнее ставит перед исследователями «итальянского феномена» вопрос о глубинных истоках проблем этой страны, связанных со специфическими чертами самой 
итальянской политической модели [6]. Так, Италия с самого начала своего существования в качестве единого государства регулярно испытывала затруднения в вопросах политической консолидации граждан. В то же время исчерпание возможностей традиционных стратегий и технологий консолидации нации вызывает к жизни нетрадиционные, что ярко проявилось на примере парламентских выборов весны 2018 года.

Методы. В рамках заявленного исследования необходимо обоснование используемой методологии. Авторы вынуждены констатировать, что в отечественной историографии отсутствуют специальные исследования, посвященные методологическим подходам к изучению политического кризиса в Италии, что не препятствует формированию целостной картины данного явления. В то же время итальянские историческая и политическая науки преуспели не только в непосредственном изучении, но и в разработке методологических подходов к изучению истоков кризисного феномена в своей стране. $\mathrm{C}$ позиций исторического, структурного и культурологического анализа они рассматривают делегитимацию институциональновластной системы Италии и поддерживающих ее политических практик.

В российской историографии методологические аспекты изучаемой проблемы затрагиваются лишь в отдельных статьях, посвященных определенным аспектам политического кризиса в Италии. При этом если в центре внимания одних авторов оказалась проблема возникновения этого феномена в итальянской истории, рассматриваемая на стыке исторического и политического анализа (В.П. Любин, Г.Н. Зевелева), то другие рассматривают основные этапы итальянского кризиса (К.Г. Холодковский), реконструируя логику политических циклов в новейшей итальянской истории. В свою очередь, третьи исследователи анализируют предпосылки современного политического кризиса с позиций социально-экономического анализа (А.В. Авилова, В.Б. Белов). В российской научной литературе, изданной за последнее время, следует выделить, прежде всего, работы И.Б. Левина, В.П. Любина и Е.А. Масловой, которые обосновывают и формируют системно-исто- рический взгляд на природу и характер итальянского кризиса.

Долгое время исследование итальянского кризиса осуществлялось преимущественно с позиций институционального анализа. Поведенческий анализ применялся при изучении поведения избирателей в контексте выборов и электоральных стратегий кандидатов. Масштабные политические трансформации 1980-х - начала 1990-х гг. создали широкие возможности для применения как case-study, так и системного анализа.

Авторы статьи стремятся к комбинации общетеоретических и специальных методов, делая основной упор на исторический, социально-культурный и политический анализ, рассматривая генезис политических проблем Италии и их воспроизведение в процессе исторического развития как следствие определенного ценностно-политического выбора общества и его политических представителей, исходя при этом из принципиальной вариативности политической истории любого государства.

Анализ. С особым опасением ожидала Европа исхода последних парламентских выборов в Италии, назначенных на 4 марта 2018 г., на которых избиратели впервые голосовали по трем спискам (общенациональному, региональному и территориальному). Состояние общественных настроений в Италии перед мартовским голосованием действительно давало основания для опасений приверженцам «объединенной Европы» и ее ценностей. От затянувшегося общенационального кризиса очевидно страдала экономика Италии, падение которой за период между 2006 и 2016 гг. составило $9 \%$, приходили в дальнейший упадок финансы (государственный долг за это же время возрос до $132 \%$ ВВП), но главное, сама модель итальянской демократии и политической системы все более явно обнаруживали свою растущую неэффективность [8]. Евроскептицистские идеи получали поддержку все большего числа итальянцев. Опрос, проведенный незадолго до выборов Институтом Жака Делора, показал, что почти половина итальянских избирателей (46 \%) связывали решение указанных проблем с выходом из ЕС [5].

Как результат, в Европейском союзе многие ожидали победы популистов (к которым 


\section{ПОЛИТИЧЕСКИЕ НАУКИ И РЕГИОНОВЕДЕНИЕ}

причислялись все основные фавориты выборной кампании 2018 г.), опасаясь очередного переноса многообразных проявлений итальянского кризиса на другие европейские страны и Европейский союз в целом. Каковы же были причины этой европейской тревоги об итальянских делах?

Первая причина - экономика, что выразилось в превращении Италии в своеобразного рекордсмена Евросоюза по размеру государственного долга вследствие многолетнего игнорирования бюджетных стандартов Брюсселя. Особая сложность ситуации была связана с тем, что проблемы Италии имели структурный и институциональный характер. К их числу было принято относить слишком большую долю госсектора в экономике, высокий уровень коррупции, устаревшую инфраструктуру, масштабные межрегиональные диспропорции, высокие налоги и значительный вес профсоюзов. Все это в совокупности делает Италию непривлекательной для иностранных инвестиций, отпугивая иностранных инвесторов, и усугубляет ситуацию в экономике, социальным недоверием и углубляющимся политическим кризисом [23]. Именно поэтому возможный отказ пришедшего к власти по итогам выборов 2018 г. «правительства популистов» принять меры по сокращению бюджетного долга рассматривался многими в ЕС как прямой вызов Пакту стабильности 2011 года.

Вторая причина - особое значение Италии для сохранения единства Евросоюза в контексте существующих глобальных и внутренних вызовов - проблематичности дальнейшего глобального лидерства США, обострившихся отношений между Западом и Россией и противоречий между странами ЕС [12]. Поэтому ответ на вопрос, сумеет ли ЕС восстановить общность целей или же он вместо этого погрузится в хаос, во многом зависел от происходящего сегодня в Италии.

Дополнительным фактором значимости Италии в рамках общеевропейской архитектуры стал произошедший раскол Европы на экономически сильный Север и «проблемную» южную периферию, страны которой в большинстве не имеют ресурсов либо политической воли для структурной перестройки экономики. Италия исторически разделена внутри себя на динамичный Север и перманентно депрессивный Юг. Преодоление этого раскола в течение новейшей истории страны так и не состоялось, что породило «взрыв» протестных и популистских настроений [18].

В ответ на это политический истеблишмент стран ЕС пытается ангажировать популистские силы, побуждая их к альянсу со вставшими на путь реформизма бывшими социал-демократическими партиями ради содействия устойчивому развитию, инновациям и инвестициям вместо евроскептицизма. Подобные коалиции должны были обеспечить поддержку проевропейски настроенным технократам-реформаторам. В то же время совокупный триумф популистов в Италии в марте 2018 г. ставил эти масштабные планы под сомнение.

Между тем помимо традиционного страха перед радикалами и опасений возможного проецирования итальянских проблем на Европу, более существенными выглядели проблемы дальнейшего политического развития самой Италии. Фрагментация политической и партийной систем на фоне произошедшего ранее ухода со сцены ведущих общенациональных политических партий (ХДП, Компартии и Соцпартии) ставила в повестку дня вопрос о том, кто же реально сможет объединить страну: политические «нотабли» и партийные патроны, либеральные технократы либо самобытные харизматичные лидеры, способные взять под контроль посредством популистской риторики поднявшуюся волну протестных настроений?

Выборы состоялись, но не принесли, как и ожидалось, абсолютной победы (необходимых для формирования однопартийного кабинета министров 40 \% голосов избирателей) ни одному из потенциальных фаворитов [13].

Первое место со значительным отрывом заняло левопопулистское «Движение пяти звезд» $(32,66 \%)$, на втором месте оказалась ранее проправительственная «Демократическая партия Италии» $(18,72 \%)$, на третьем - право-популистская партия «Лига Севера» (17,37\%), на четвертом - позиционирующая себя в качестве правоцентристского объединения партия «Вперед, Италия!» $(14,01 \%)$. Трехпроцентный барьер также смогли преодолеть ультраправые «Братья Италии» 
$(4,35 \%)$ и умеренно правые «Свободные и равные» $(3,38 \%)$, оставив вне парламента более мелкие партийные объединения правого, левого и центристского толков.

По сравнению с 2013 г. «Демократическая партия Италии» и «Вперед, Италия!» лишились части голосов, в то время как «Движение пяти звезд» и «Лига Севера» получили дополнительно $6,62 \%$ и 13,59 \% соответственно. В сумме за две эти партии, известные своими евроскептицистскими установками, было подано свыше 50 \% голосов избирателей. Политический выбор, сделанный различными группами избирателей, лишь подтвердил наличие ценностного раскола в итальянском обществе на сторонников проевропейской модернизации «сверху» (голосовавшие за «Демократическую партию Италии»), антисистемно настроенных критиков «европейского выбора» (сторонники «Движения пяти звезд»), консервативных романтиков и сторонников «Великой Италии» (приверженцы «Братьев Италии») и приверженцев сильных харизматических личностей с их особыми подходами к решению проблем страны («Вперед, Италия!» С. Берлускони). Приход «антисистемных» политиков во власть стал подлинным шоком для политического истеблишмента страны. Как следствие, политическое оформление итогов прошлогоднего мартовского волеизъявления прошло весьма напряженно.

В процессе формирования правительственной коалиции рассматривались различные варианты - от объединения всех «правых» сил вокруг партии С. Берлускони до формирования альянса «Демократической партии Италии» и «Движения пяти звезд» (что приветствовали в Брюсселе). В результате двухмесячных консультаций сформировалась «большая популистская коалиция» в составе «Лиги Севера» и «Движения пяти звезд», представившая в итоге президенту Италии для утверждения на пост премьера формально беспартийного юриста Джузеппе Конте, что было расценено некоторыми экспертами как «политический поворот», угрожающий перспективам «единой Европы» [22].

Означали ли прошедшие выборы без однозначного победителя неуправляемую Италию? Оставался открытым вопрос о том, вокруг каких ценностных и идеологических оснований будет осуществляться новая «сборка» итальянской политической системы. И было неясно, распадется ли знаменитая комбинация «демократического султаната» и атомизированного популизма вкупе с политическими технологиями, наличие которой в итальянской политике отмечал знаменитый Джованни Сартори [7].

Уникальность «случая Италии» состояла в том, что в ситуации усталости от «игр» партийной элиты новое гражданское движение практически приобрело против всей старой политической системы и против самого итальянского государства. В итоге политический популизм, выступающий в качестве своеобразной «интегральной» идеологии формирующегося «снизу» движения протеста, стал новой идейной и политической «скрепой» страны.

Следует признать, что трансформации партийной системы Италии начиная с 1992 г. привели в итоге не к формированию устойчивой «двухпартийности», а к ситуации «неуправляемой многопартийности» и фрагментации партийной системы. Конкуренция и компромиссы между «правоцентристской» и «левоцентристской» (интегрированной в леволиберальный мейнстрим в духе идей Г. Шредера и Т. Блэра) коалициями не могли удовлетворить политические запросы граждан. Возникшие на рубеже 2010-х гг. массовые гражданские политические движения протеста, связанные с неприятием политических и социально-экономических стратегий истеблишмента, разрушили устоявшуюся систему сдержек и противовесов и привычный для истеблишмента механизм формирования правительственных коалиций. Поэтому успех политических движений протестного толка на выборах 2013 г. и особенно 2018 г. в Италии ставил в повестку дня вопрос о глубокой трансформации политической системы Италии.

При этом уникальность ситуации в Италии заключается в том, что по итогам парламентских выборов 2018 г. был создан альянс «левых» («Движение пяти звезд») и «правых» («Лига Севера») популистов, что оставило политическому истеблишменту довольно ограниченное пространство для маневра в отличие Франции, где антисистемные силы оста- 
ются разделенными по идеологическому принщипу.

Предпосылкой для формирования этого альянса стало соединение в программе «Движения пяти звезд» как собственно «левых» (идея прямой демократии, враждебность к партиям, идея социальных гарантий), так и «правых» (антиевропейская и антимигрантская риторика, критика высокого налогообложения и чрезмерного государственного «вмешательства») по своему характеру положений [9]. Дорогу к успеху «Движению пяти звезд» расчистили как традиционные доктринальные «левые» (которые сегодня маргинализированы после самороспуска Итальянской коммунистической партии и трансформаций Социалистической партии в 1990-е гг.), так и системные «левые» в лице действующей «Демократической партии Италии» (перешедшей на платформу неолиберализма и продвигающей ныне идеи европейской интеграции).

Однако электоральной поддержки «Движению пяти звезд» было недостаточно для формирования однопартийного правительства, поскольку последним для прихода во власть был необходим сильный партнер с «правого» фланга итальянской политики, где в последние годы также происходили серьезные изменения. Предыдущие версии правоцентристской коалиции в Италии, во главе которых вместе с формируемыми им объединениями («Вперед, Италия!» и «Народ свободы») стоял enfant terrible Евросоюза Сильвио Берлускони, была и ранее одной из наименее «системных» (и принимаемых таковыми) в Европе. Однако фактическая утрата Берлускони возможности выступать в качестве «центра консолидации» для всех «правых» вследствие снижения уровня поддержки возглавляемых им партий и движений. На фоне ослабления позиций лагеря «берлусконианцев», «Лига Севера» во главе с новым лидером Маттео Сальвини после 2011 г. успешно осуществила ребрендинг, перейдя от имиджа сравнительно умеренной либерально-консервативной партии с регионалистской повесткой к роли общенациональной правопопулистской партии с евроскептицистской программой [4].

Сближению «Лиги Севера» с укрепившими свои позиции «левыми популистами» способствовало и то, что в 2013 г. «Лига Севе- ра», единственная из крупных старых партий, не вошла в коалицию «все против Пяти звезд» и бросила вызов действующему политическому истеблишменту. По результатам выборов 2018 г. впервые «Лига Севера» набрала больше голосов, чем партия Берлускони (17\% против $14 \%$ ), что позволило Сальвини заявить о собственных премьерских амбициях и самостоятельно начать искать партнеров для будущей коалиции. Возникший по итогам выборов 4 марта 2018 г. популистский альянс создал условия для «перезагрузки» политической системы, складывавшейся в течение многих лет в Италии.

Между тем мартовские выборы 2018 г. создали возможность для нарушения циклической закономерности, в соответствии с которой происходило политическое развитие страны в новейший период ее истории. Политическая история Италии после Второй мировой войны обнаруживает специфическое чередующееся доминирование «левых» и «правых» идей на уровне национальной политики (так называемый «левоправый маятник», способствовавший не равновесию, но дестабилизации итальянской политической системы). Итальянские «правые» и «левые», сменяя друг друга у власти, зачастую не имели возможности закрепить свое доминирование институционально, поскольку сталкивались с сопротивлением своих идеологических конкурентов и протестными настроениями «снизу». Подобное стало возможным благодаря исторически сложившемуся разделению общенациональной политической культуры на некомплементарные субкультуры (по версии Р. Патнэма, на гражданско-индивидуалистическую культуру Севера и коллективистско-патерналистскую культуру Юга) [20, p. 135].

Государство в Италии так и не стало полновластным центром политической консолидации и было оплетено системой дополняющих его неформальных связей («аморальная семейственность») [2]. Многолетняя слабость политических институтов была компенсирована значительным весом регионов и региональных лобби, а равно и клиентелизмом, опирающимся на разветвленные сети, охватившие своим влиянием всю страну [17].

Нация, формируемая «сверху» усилиями классической веберианской бюрократии и не 
обладающая консолидированной общенациональной (общегражданской) политической культурой, не доверяла в полной мере выступающему от ее имени государству и регулярно бросала вызов истеблишменту.

В итоге содержание политического процесса в значительной степени определял периодически приводимый в действие итальянскими политиками механизм инверсии, означающей процесс продвижения модернизационных на базе политической культуры со значительным присутствием элементов традиционализма [1]. Последнее создавало возможности не только для идеологического и политического манипулирования, но и для откровенного злоупотребления властью.

Инверсия не позволила завершить процесс институциональных преобразований в интересах большинства итальянских граждан, не дала возможности легитимировать должным образом основные существующие и возникающие в процессе развития общества политические институты [14]. Последнее создает значительное пространство для утверждения патронажно-клиентарных отношений и реализации корпоративных интересов истеблишмента, что в результате вызывало недоверие избирателей к истеблишменту и приводило к политическим кризисам, порождая массовые протестные движения популистского и антисистемного толка.

Попытка проводить любой последовательный (либеральный, технократический, социально ориентированный и т. п.) политический курс в подобных условиях неизбежно наталкивалась на подъем протестных настроений, что в итоге означало неудачу многих преобразовательных начинаний.

Данная закономерность подтверждается ходом послевоенной итальянской истории. Социокультурная инверсия в новейшей истории Италии порождала чередование некомплементарных политико-идеологических платформ и программ без итогового достижения долгосрочных компромиссов и их надлежащего институционального и правого закрепления.

Послевоенный период характеризовался доминированием Христианско-демократической партии Италии (далее - ХДП), которая апеллировала к ценностям католицизма и проводила политику делегитимации поли- тических конкурентов (прежде всего коммунистов). При этом политико-идеологическая монополия демохристиан не была абсолютной. В 1960-е гг. происходят активизация неофашизма и ответный подъем массового антифашистского движения. На 1969 г. приходится так называемая «Жаркая осень» (борьба за новые условия коллективных трудовых соглашений и расширение прав рабочих организаций), вскоре сменившаяся наступлением эры организованной преступности и политического экстремизма, всколыхнувшей страну и поставившей ее на грань установления «правой» диктатуры (по аналогии с режимом «черных полковников» в Греции). Проводившаяся в 1976-1979 гг. политика «национальной солидарности» ненадолго стабилизировала страну. Межпартийный компромисс привел в 1980-е гг. к ситуации, когда последовательно сменявшие друг друга правительства с участием тогдашних основных пяти партий (ХДП, ИСП, социал-демократы, республиканцы, либералы) не преуспели в решении социально-экономических проблем Италии. В итоге парламентские выборы 1992 г. обнаружили фактическое банкротство основных системообразующих политических партий, что означало дефолт существовавшей на тот момент партийной системы.

Реакцией на возникший кризис стал происходивший в течение 1991-1993 гг. переход от пропорциональной избирательной системы к мажоритарной, сопровождавшийся масштабными антикоррупционными скандалами («Тагентополи»), кризисом традиционных правительственных партий и выходом на арену новых политических сил [10]. 4 августа 1993 г. был одобрен новый закон о парламентских выборах, ознаменовавший переход ко Второй республике в Италии.

Двумя новыми политическими акторами в итальянской политике в 1990-х гг. стали Сильвио Берлускони, медиа-магнат, пришедший в большую политику весной 1994 г., создатель и лидер движения «Вперед, Италия!» («Forza Italia»), и Умберто Босси, человек «возникший ниоткуда» (venuto dal niente), лидер «Лиги Севера» («Lega Nord») - регионалистского движения, возникшего в Венеции и Ломбардии и завоевавшего значительную поддержку первоначально в северных регионах страны. 
Ярким явлением популизма в итальянской политике стали выборы 1994 года. На этих выборах Берлускони и Босси, политические конкуренты в будущем, выступили союзниками в северной части страны, в то время как в центральной и южной Италии Берлускони и его движение выступали в связке с «Национальным альянсом» («Alleanza Nazionale»), так называемой постфашистской партией, руководимой тогда скандально знаменитым Джанфранко Фини [15].

Сформированный по итогам выборов 1994 г. трехпартийный кабинет просуществовал в итоге полгода. И хотя идеология всех трех представленных в нем партий содержала в себе популистские элементы, основные политические дивиденды из этого извлекла лишь партия медиамагната.

Отдельного рассмотрения в контексте свершившейся тогда «популистской революции» заслуживает феномен Сильвио Берлускони. Последний, будучи изначально убежденным либералом в экономике с некоторыми элементами консерватизма в политике, постепенно эволюционировал в направлении «правого» популизма без ущерба для собственного имиджа политического «тяжеловеса» и европейского политика.

Идеологическая и политическая многоликость экс-премьера уникальным образом консолидировала расколотую страну, проходя над линиями мировоззренческих расколов и внедряя своеобразный антиполитический стиль [19]. Берлускони и активно продвигаемый им проект «Вперед, Италия!» в глазах избирателей с севера страны имели либерально-консервативный имидж, в то время как в сознании жителей юга - ярко выраженный патерналистский. Если для северян он являлся примером сильной, успешной и самодостаточной личности, то в глазах южан выступал как сильная фигура, способная содействовать решению накопившихся проблем и защитить привыкшего к опеке «маленького человека». Таким образом, Берлускони выступил в ситуации кризиса как политический нотабль и медиатор на «правом» фланге итальянской политики, генерируя и одновременно направляя в приемлемое для политического истеблишмента русло поднимавшуюся тогда популистскую «волну», не давая ей превратиться в полноценное движение протеста.

Начиная с 1994 г. Сильвио Берлускони четырежды становился премьер-министром Италии, занимая этот пост с перерывами до ноября 2011 года. Заменивший на время прежнюю партию Берлускони «Народ свободы» с 2008 по 2013 г. имел большинство в обеих палатах парламента, и лишь в 2011 г. под нажимом Евросоюза С. Берлускони и его однопартийцы согласились на формирование «переходного» правительства во главе с формально беспартийным экс-комиссаром ЕС Марио Монти, подвергнув критике его программу «финансовой стабилизации».

Парламентские выборы, прошедшие 2425 февраля 2013 г., не принесли ощутимого преимущества ни одной из участвовавших в них партий. Сложился своеобразный тупик в отношениях между левоцентристским блоком во главе с Демократической партией Пьера Берсани, получившим большинство в Палате депутатов, и правоцентристским блоком во главе с «Народом свободы» С. Берлускони, который получил тогда большинство в Сенате [11]. После разразившегося тогда правительственного кризиса, вызванного нежеланием ведущих партий страны договариваться и неприятием ими фигуры Берлускони (людей которого рекомендовал тогда включить в правительство действовавший президент Италии Д. Наполитано). Однако компромисс был в итоге найден в виде коалиции из представителей Демократической партии, партий «Народ свободы», «Гражданский выбор» М. Монти и беспартийных. 24 апреля 2013 г. президент страны предложил лидеру Демократической партии Энрико Летте возглавить новое правительство Италии. В итоге 27 апреля 2013 г. кабинет министров был сформирован и представлен президенту, который привел его на следующий день к присяге.

Влияние Берлускони, которого продолжала активно защищать его собственная партия, было нейтрализовано благодаря начавшемуся против него тогда судебному процессу и домашнему аресту, что не помешало его однопартийцам и дальше бороться за сохранение для патрона места в политике.

Правительство Летты представляло собой второй подряд технократический каби- 
нет без прочной парламентской опоры, но с поддержкой президента, что не мешало новому премьеру активно продвигать свой публичный образ и выдвигать политические инициативы [16]. Вступивший в свои полномочия в мае 2013 г. премьер Летта с самого начала определил лейтмотивом работы своего кабинета «Bene»! («Хорошо!») и пообещал работать не в интересах партий, а ради общего блага, что неизбежно требовало преодоления ожесточенной межпартийной конкуренции последних 20 лет, которая стала поистине разрушительной для страны. В то же время неудачи правительства Летты в решении проблем судебной системы, стимулирования экономического роста и повышения занятости молодежи предопределили досрочный уход кабинета 14 февраля 2014 года. Демократическая партия поддержала предложение своего недавно избранного председателя Маттео Ренци о смене правительства Италии. Президент Италии Д. Наполитано принял эту отставку, предложив Ренци как политическому «тяжеловесу» возглавить кабинет самому.

63-е правительство Итальянской Республики приступило к работе с 22 февраля 2014 г. под председательством Маттео Ренци, бывшего социалиста и действующего лидера Демократической партии, инициировавшего масштабные реформы избирательного и трудового законодательства. Ренци отметился проведением через парламент в 2014-2015 гг. так называемого Акта о занятости (Jobs Act), призванного обеспечить большую «мобильность» рабочей силы и вызвавшего неоднозначную реакцию среди политиков и в обществе. Он также инициировал реформу избирательного законодательства с целью облегчить процедуру формирования правительства на многопартийной основе (была поддержана в парламенте, но не введена в силу).

Однако реформаторские начинания неизбежно сталкивались с особенностями институциональной системы страны. Одна из наиболее значимых в «пакете реформ» Ренци предполагала преобразование Сената, что означало очевидный сдвиг в направлении «мажоритарной» (фактически президентской) демократии.
В этой связи следует напомнить, что Сенат - один из ключевых институтов итальянской политической системы. В послевоенной республиканской Италии избираемый на пропорциональной основе Сенат был важным институтом в системе разделения властей, выступая в роли законодательного «фильтра» в отношении законопроектов, исходящих из нижней палаты парламента, а также обладал правом, наряду с нижней палатой, ставить вопрос о доверии кабинету министров. Привилегированный статус сенаторов являлся значимым элементом итальянской системы клиентелизма, превращая их в своего рода нотаблей, включающих в собственные сети влияния региональных советников и мэров.

Задуманная Ренци конституционная реформа имела целью коренное изменение процесса формирования Сената страны, существенное урезание его функций и сокращение численности верхней палаты с 315 до 100 человек. Сохранив название «Сенат», верхняя палата включала бы в себя 95 членов, делегируемых региональными советами (21 мэра и 74 региональных советников-сенаторов), и еще 5 сенаторов, назначаемых главой государства на семилетний срок. Законодательные же функции, а также право голосовать за отставку правительства или отдельных министров должны были стать прерогативой нижней палаты парламента. Все это в совокупности означало конец так называемого «совершенного» бикамерализма и создавало возможность для дальнейших реформ. Будучи проголосованной в начале 2016 г. в итальянском парламенте без участия оппозиции, эта реформа расколола и поляризовала итальянское общество, вызвав неприятие со стороны всех основных политических партий страны.

Показательно, что еще до проведения референдума о реформе Сената Демократическая партия Италии получала подтверждения о снижении уровня поддержки ее политики избирателями в 2014-2015 гг. почти на треть по сравнению с парламентскими выборами 2013 г., в то время как оппозиционная «Лига Севера» заметно усилила свои позиции. В итоге статус Демократической партии в качестве «ядра» партийной и политической систем страны был поставлен под вопрос. 
Проиграв референдум о реформе итальянского Сената от 4 декабря 2016 г., Маттео Ренци уже на следующий день подал в отставку. Таким образом, исповедуемый им умеренный реформистский популизм потерпел неудачу. В итоге постидеологический лидер, воспринявший сформированный Берлускони тренд на персонализацию лидерства и исповедовавший сугубо инструменталистский подход к политике, так и не сумел убедить избирателей в искренности своих намерений [3].

Избиратели не поверили умеренно-популистской риторике Ренци, направленной против истеблишмента, восприняв его инициативу с референдумом как очередной маневр «правящего класса» с целью сохранить свою власть вместо решения накопившихся проблем. Сам имидж премьера как «человека со стороны», не связанного с истеблишментом, также оказался размыт.

Премьер-министр Ренци не сумел понять, что итальянские избиратели, в соответствии с упомянутым выше механизмом инверсии, после долгих лет кризиса желали не примирения на «центристской» платформе, а полноценного реванша в отношении все менее популярных представителей «политического класса». На их «рессентимент» в отношении собственных государства и истеблишмента наложилось неприятие политики европейских элит, проводником которой все более очевидно выглядел изначально популярный в массах Ренци.

Неудача реформаторов-технократов означала провал стратегии ре-консолидации истеблишмента и объединения вокруг него рядовых граждан на своеобразной «постидеологической» платформе. В результате политических неудач «партийного патрона» Берлускони и проевропейски ориентированных технократов именно популизм стал единственной политической силой и идеологией, способной ответить на запросы и настроения кризисного итальянского общества. Как результат, политические объединения популистского толка стали определять повестку дня итальянской политики.

Роль популизма в политической жизни Италии между тем является весьма неоднозначной. С одной стороны, он позволил умереть собственно политической жизни и поли- тике (при всем их карнавальном характере) в ситуации распада партий и снижения популярности основных политических институтов. Именно популизм (при всех известных связанных с ним политических рисках и издержках) не позволил окончательно подменить публичную политику бюрократическими согласованиями в Риме и Брюсселе. Он также сохранил политическое многообразие и политическую интригу на выборах, не дал окончательно устояться «коалиции истеблишмента» («коалиции беспринципных»), имеющей целью сохранение политического «статускво» вместо необходимых изменений для общества. Не менее важно, что популизм способен специфическим образом собрать воедино итальянское общество, разделенное на обособленные друг от друга корпоративные, региональные и кланово-партийные сегменты, что так и не удалось сделать в рамках предшествующих политических проектов. Именно популизм в качестве политической идеи и практики позволил Италии избежать критического углубления кризисов проникновения и легитимности, способных парализовать основные политические институты страны. Наряду с этим, состоявшийся «лево-правый» синтез дает Италии шанс на постепенное преодоление идеологических расколов и крайностей. Наконец, именно политическое торжество популистов обоих толков дает шанс на действительное преодоление закрытости политического класса и патронажно-клиентарных практик, являющихся причиной общей низкой эффективности итальянской политической системы.

Вместе с тем торжествующий по итогам парламентских выборов «лево-правый» популизм 2018 г. пока оставляет без ответа ключевые вопросы политического и социально-экономического бытия Италии, равно как и соответствующие формы институционального выражения нового соотношения политических сил страны. При этом уникальность итальянской ситуации заключается в том, что для оправдания колоссального доверия со стороны общества первому в «Старой» Европе «правительству популистов» придется находить и реализовывать эффективные пути решения накопившихся в стране проблем. 
Результаты. Анализ современного политического процесса и опыта предшествующего политического развития Италии показывает, что стране до последнего времени не удавалось выйти за рамки так называемой «модернизационной ловушки». Неоднородность политической культуры не позволяла консолидировать нацию и построить эффективные и ответственные перед обществом политические институты, слабость которых периодически генерировала масштабные общенациональные политические кризисы.

Итальянское государство и поддерживающий его политический класс (включая сюда партийных «нотаблей» и «корпорацию» сенаторов) являли собой своеобразную надстройку, обеспечивающую единство страны. Нараставшее в течение десятилетий недовольство в итоге вылилось в глубокий политический кризис 1990-х гг., в рамках которого можно выделить кризис проникновения (связанный с низкой эффективностью реализации властноуправленческих решений на различных уровнях), кризис легитимности (охватывающий основные политические институты страны), кризис участия (связанный с низким уровнем доверия итальянцев к политическим институтам) и кризис распределения (вызванный неспособностью национального политического класса обеспечить приемлемый для общества уровень благосостояния и эффективное распределение воспроизводимых благ).

Технократы, приверженные стратегии макроэкономической стабилизации и связанные с истеблишментом Брюсселя, не обнаружили в себе властно-управленческого и личного (харизматического) ресурсов, позволяющих консолидировать итальянскую нацию. Достигнуть этой цели не смогли и их оппоненты из числа новых партийных элит, сформировавшихся в течение двух последних десятилетий. Подобная ситуация создала широкие возможности для политиков популистского толка не только в смысле политического самоутверждения, но и в деле трансформации политического устройства и модернизации экономики и социальной сферы страны.

Осуществленный нами анализ процессов политического развития Италии подтверждает тезис о том, что современные государство и общество являются продуктом комплексной модернизации, охватывающей все основные сферы жизни, незавершенность которой порождает внутренние расколы и кризисы.

С этой точки зрения Италия (как сравнительно поздно возникшее национальное государство) была обречена на модернизацию «сверху», проводимую усилиями государства (согласно формуле Массимо де Адзельо «Мы создали Италию, осталось создать итальянцев»). При этом сопротивление периодически повторяющимся попыткам глубоких модернизационных реформ было вызвано неоднородностью итальянского социума, культурными различиями между историческими регионами Италии и, прежде всего, сопротивлением истеблишмента, который превратился в Италии в разновидность «наследственной аристократии».

Попытки глубоких политических и экономических трансформаций регулярно сталкивались с несовершенством институционально-властной системы и сопротивление того же истеблишмента, защищающего клиентарную модель своего влияния и вытекающие из нее привилегии. Ответом на незавершенные реформы являлся скачкообразный подъем популизма, торжество которого приводило к сохранению патримониальных оснований клиентарной политики и ориентированных на них старых (новых) элит.

Как результат, именно популизм и клиентелизм (а не какие-либо идеологические, институциональные и партийные структуры) традиционно выполняли роль консолидирующих механизмов в итальянской политике.

Более глубокая причина неудач реформаторских начинаний была связана с тем, что в Италии не утвердилась традиция политического и идеологического центризма, примиряющего «полюса» на уровне общенациональной политики. Слабость общенациональной гражданской культуры породила феномен инверсии, когда прогрессивные политические лозунги подкреплялись традиционалистскими (контрмодернизационными) практиками, а торжество правых в политике сменяется экспансией левых, и наоборот.

Идеологические партии (демохристиане и социалисты), поставившие под собственный контроль государство и его аппарат, вызывали в обществе протестные настроения. Ита- 


\section{ПОЛИТИЧЕСКИЕ НАУКИ И РЕГИОНОВЕДЕНИЕ}

льянское общество рассматривало государство как внешнюю силу, а многие его инициативы - как покушение на устоявшийся образ жизни. Ответом становится популизм (как «правого», так и «левого» толка).

С этой точки зрения парламентские выборы в марте 2018 г., которые привели к власти «лево-правую» коалицию популистов, стали своеобразным прорывом, выходящим за рамки устоявшегося политического цикла. По мнению авторов, в современной итальянской ситуации популизм может превратиться в средство, соединяющее и нейтрализующее разделяющие страну политико-идеологические крайности и способное остановить описанный нами «маятник инверсии». В современной ситуации глубокого кризиса Республики и ее институтов именно консолидированный популизм может превратиться в ключевую «скрепу» современной итальянской политики, если «коалиция популистов» сможет выработать и начать проводить в жизнь действительно прагматический политический и социально-экономический курс, выражающий и согласующий интересы различных социальных групп. Именно этот путь, по мнению авторов, позволит избежать дефолта политической системы и вывести Италию на путь эволюционного и устойчивого политического развития.

\section{СПИСОК ЛИТЕРАТУРЫ}

1. Лисовский, Ю. П. Политическая культура Италии / Ю. П. Лисовский, В. П. Любин. - М. : ИНИОН, 1996. $-64 \mathrm{c}$.

2. Banfield, E. C. Moral Basis of a Backward Society / E. C. Banfield. - Chicago : The Free Press, 1958. $-204 \mathrm{p}$.

3. Bordignon, F. Matteo Renzi: A 'Leftist Berlusconi' for the Italian Democratic Party? /F. Bordignon // South European Society and Politics. 2014. - Vol. 19, № 1. - P. 1-23. - DOI: https://doi.org/ 10.1080/13608746.2014.887240.

4. Brunazzo, M. Insurgents Against Brussels: Euroscepticism and the Right-Wing Populist Turn of the Lega Nord since 2013 / M. Brunazzo, M. Gilbert // Journal of Modern Italian Studies. - 2017. - Vol. 22, № 5. - P. 624-641. - DOI: https://doi.org/10.1080/ 1354571X.2017.1389524.

5. Bussard, St. En Italie, les élections de la peur / St. Bussard // Le Temps. - 2018. - 18 février. -
Electronic text data. - Mode of access: https://www. letemps.ch/opinions/italie-elections-peur (date of access: 10.11.2018). - Title from screen.

6. Calise, M. Dopo la partitocrazia. L'Italia tra modelli e realtà /M. Calise.-Torino: Einaudi, 1994. - 173 p.

7. Carbone, M. Democratic Sultanate, Atomised Pluralism, Political Engineering: Sartori and the Paradoxes of the Italian Political System / M. Carbone // Contemporary Italian Politics. - 2017. - Vol. 9, № 3.P. 225-228. - DOI: https://doi.org/10.1080/23248823. 2017.1394565.

8. Ceccarini, L. Referendum on Renzi: The 2016 Vote on the Italian Constitutional Revision / L. Ceccarini, F. Bordignon // South European Society and Politics. 2017. - Vol. 22, № 3. - P. 281-302. - DOI: https://doi.org/ 10.1080/13608746.2017.1354421.

9. Ceccarini, L. The Five Stars Continue to Shine: the Consolidation of Grillo's 'Movement Party' in Italy / F. Bordignon, L. Ceccarini // Contemporary Italian Politics. - 2016. - Vol. 8, № 2. - P. 131-159. - DOI: https://doi.org/10.1080/23248823.2016.1202667.

10. Crainz, G. Italy's Political System since 1989 / G. Crainz // Journal of Modern Italian Studies. - 2015. Vol. 20, № 2. - P. 176-188. - DOI: https://doi.org/ 10.1080/1354571X.2015.997490.

11. D'Alimonte, R. The Italian Elections of February 2013: the End of the Second Republic? / R. D'Alimonte // Contemporary Italian Politics. 2013. - Vol. 5, № 2. - P. 113-129. - DOI: https://doi.org/ 10.1080/23248823.2013.807599.

12. Eaton, J. Italy and the European Crisis: Panel Discussion / J. Eaton // Journal of Modern Italian Studies. - 2014. - Vol. 19, № 4. - P. 396-403. - DOI: https://doi.org/10.1080/1354571X.2014.929824.

13. Elezioni politiche: vincono M5s e Lega. Crollo del Partito democratico. Centrodestra prima coalizione. Il Carroccio sorpassa Forza Italia // La Repubblica. 2018. - 4 Mars. -Electronic text data. - Mode of access: http://www.repubblica.it/speciali/politica/elezioni2018/ 2018/03/04/news/risultati_elezioni_politiche_pd_ centrodestra_m5s_fi_lega-190424815/(date of access: 11.11.2018). - Title from screen.

14. Gervasoni, M. Political Delegitimation in Republican Italy, 1945-2011 / M. Gervasoni, G. Orsina // Journal of Modern Italian Studies. - 2017. - Vol. 22, № 1. - P. 1-6. -DOI: https://doi.org/10.1080/1354571X. 2017.1267977.

15. Gobetti, D. La Lega: Regularities and Innovation in Italian Politics / D. Gobetti // Politics \& Society. - 1996. - Vol. 24, № 1. - P. 57-82. - DOI: https://doi.org/10.1177/0032329296024001006.

16. Heisig, J. Italien am Scheidenweg / J. Heisig // WeltTrends. - 2013. - № 93. - S. 15-17.

17. Musella, L. The Notabile as Actor and Model of Italian Politics / L. Musella // Journal of Modern Italian Studies. - 2016. - Vol. 21, № 5. - 
P. 707-722. - DOI: https://doi.org/10.1080/1354571X. 2016.1242258 .

18. North-South Divide in Italy: A Problem for Europe Too // New York Times. - 1996. - 11 Nov. Electronic text data. - Mode of access: https://www. nytimes.com/1996/11/15/world/north-south-divide-initaly-a-problem-for-europe-too.html (date of access: 10.11.2018). - Title from screen.

19. Pasquino, G. The Five Faces of Silvio Berlusconi: The Knight of Anti-Politics / G. Pasquino // Modern Italy. - 2007. - Vol. 12, № 1. - P. 39-54. DOI: https://doi.org/10.1080/13532940601134817.

20. Putnam, R. Making Democracy Work: Civic Traditions in Modern Italy / R. Putnam. - Princeton : Princeton University Press, 1993. - 247 p.

21. Salvadori, M. Storia d'Italia e crisi di regime: alle radici della politica italiana / M. Salvadori. Bologna : Il Mulino, 1994. - $111 \mathrm{p}$.

22. Spralinger, A. Italiens Populisten haben entschieden: Ein Politik-Neuling soll Ministerpräsident werden / A. Spralinger // Neue Zürcher Zeitung. 2018. - 21 Mai. - Electronic text data. - Mode of access: https://www.nzz.ch/international/politik-neulingconte-soll-neuer-regierungschef-in-italien-werden1d.1387465 (date of access: 11.11.2018). - Title from screen.

23. Talving, L. Has Economic Voting Changed? A Comparative Analysis of Italy and Other Southern European Countries / L. Talving, S. Braghiroli // Contemporary Italian Politics. - 2017. - Vol. 9, № 1.P. 84-107. - DOI: https://doi.org/10.1080/23248823. 2017.1288361.

\section{REFERENCES}

1. Lisovskiy Yu.P., Lyubin V.P. Politicheskaya kultura Italii [Political Culture of Italy]. Moscow, INION Publ., 1996. 64 p.

2. Banfield E.C. Moral Basis of a Backward Society. Chicago, The Free Press, 1958. 204 p.

3. Bordignon F. Matteo Renzi: A 'Leftist Berlusconi' for the Italian Democratic Party? South European Society and Politics, 2014, vol. 19, no. 1, pp. 123. DOI: https://doi.org/10.1080/13608746.2014.887240.

4. Brunazzo M., Gilbert M. Insurgents Against Brussels: Euroscepticism and the Right-Wing Populist Turn of the Lega Nord Since 2013. Journal of Modern Italian Studies, 2017, vol. 22, no. 5, pp. 624-641. DOI: https://doi.org/10.1080/1354571X.2017.1389524.

5. Bussard St. En Italie, les élections de la peur. Le Temps, 2018, février 18. URL: https://www.letemps. ch/opinions/italie-elections-peur (accessed 10 November 2018).

6. Calise M. Dopo la partitocrazia. L'Italia tra modelli e realtà. Torino, Einaudi, 1994. 173 p.
7. Carbone M. Democratic Sultanate, Atomised Pluralism, Political Engineering: Sartori and the Paradoxes of the Italian Political System. Contemporary Italian Politics, 2017, vol. 9, no 3, pp. 225-228. DOI: https://doi.org/10.1080/23248823.2017.1394565.

8. Ceccarini L., Bordignon L. Referendum on Renzi: The 2016 Vote on the Italian Constitutional Revision. South European Society and Politics, 2017, vol. 22, no. 3, pp. 281-302. DOI: https://doi.org/10.1080/ 13608746.2017.1354421.

9. Ceccarini L., Bordignon L. The Five Stars Continue to Shine: The Consolidation of Grillo's 'Movement Party' in Italy. Contemporary Italian Politics, 2016, vol. 8, no. 2, pp. 131-159. DOI: https:// doi.org/10.1080/23248823.2016.1202667.

10. Crainz G. Italy's Political System Since 1989. Journal of Modern Italian Studies, 2015, vol. 20, no. 2. pp. 176-188. DOI: https://doi.org/10.1080/1354571X. 2015.997490.

11. D'Alimonte, R. The Italian Elections of February 2013: The End of the Second Republic? Contemporary Italian Politics, 2013, vol. 5, no. 2. pp. 113-129. DOI: https://doi.org/10.1080/23248823. 2013.807599.

12. Eaton J. Italy and the European Crisis: Panel Discussion. Journal of Modern Italian Studies, 2014, vol. 19, no. 4, pp. 396-403. DOI: https://doi.org/10.1080/ 1354571X.2014.929824.

13. Elezioni Politiche: Vincono M5s e Lega. Crollo del Partito democratico. Centrodestra Prima coalizione. Il Carroccio sorpassa Forza Italia. La Repubblica, 2018, Mars 4. URL: http://www.repubblica.it/speciali/politica/ elezioni2018/2018/03/04/news/risultati_elezioni politiche_pd_centrodestra_m5s_fi_lega- $190424815 /$ (accessed 11 November 2018).

14. Gervasoni M., Orsina G. Political Delegitimation in Republican Italy, 1945-2011. Journal of Modern Italian Studies, 2017, vol. 22, no. 1, pp. 1-6. DOI: https://doi.org/10.1080/1354571X.2017.1267977.

15. Gobetti D. La Lega: Regularities and Innovation in Italian Politics. Politics \& Society, 1996, vol. 24, no 1, pp. 57-82. DOI: https://doi.org/10.1177/ 0032329296024001006.

16. Heisig J. Italien am Scheidenweg. WeltTrends, 2013, no. 93. pp. 15-17.

17. Musella L. The Notabile as Actor and Model of Italian Politics. Journal of Modern Italian Studies, 2016, vol. 21, no. 5, pp. 707-722. DOI: https:// doi.org/10.1080/1354571X.2016.1242258.

18. North-South Divide in Italy: A Problem for Europe Too. New York Times, 1996, November 11. URL: https://www.nytimes.com/1996/11/15/world/northsouth-divide-in-italy-a-problem-for-europe-too.html (accessed 10 November 2018).

19. Pasquino G. The Five Faces of Silvio Berlusconi: The Knight of Anti-politics. Modern Italy, 


\section{ПОЛИТИЧЕСКИЕ НАУКИ И РЕГИОНОВЕДЕНИЕ}

2007, vol. 12, no. 1. pp. 39-54. DOI: https://doi.org/ 10.1080/13532940601134817.

20. Putnam R. Making Democracy Work: Civic Traditions in Modern Italy. Princeton, Princeton University Press, 1993. 247 p.

21. Salvadori M. Storia d'Italia e crisi di regime: alle radici della politica italiana. Bologna, Il Mulino, $1994.111 \mathrm{p}$.

22. Spralinger A. Italiens Populisten haben entschieden: Ein Politik-Neuling soll Ministerpräsident warden. Neue Zürcher Zeitung, 2018, Mai 21. URL: https://www.nzz.ch/international/politik-neulingconte-soll-neuer-regierungschef-in-italien-werden1d.1387465 (accessed 11 November 2018).

23. Talving L., Braghiroli S. Has Economic Voting Changed? A Comparative Analysis of Italy and Other Southern European Countries. Contemporary Italian Politics, 2017, vol. 9, no. 1, pp. 84-107. DOI: https://doi.org/10.1080/ 23248823.2017.1288361.

\section{Information about the Authors}

Sergey V. Biryukov, Doctor of Sciences (Politics), Professor, Researcher, Centre for Russian Studies, East China Normal University, North Zhongshan Road, 3663, 200062 Shanghai, China, birs.07@mail.ru, https://orcid.org/0000-0003-4071-0464

Alexander M. Barsukov, Candidate of Sciences (Politics), Deputy Dean of the Faculty of Politics and International Relations, Siberian Institute of Management, Branch of the Russian Presidential Academy of National Economy and Public Administration, Nizhegorodskaya St., 6, 630102 Novosibirsk, Russian Federation, amb2@inbox.ru, https://orcid.org/0000-0002-7768-0097

\section{Информация об авторах}

Сергей Владимирович Бирюков, доктор политических наук, профессор, научный сотрудник Центра изучения России, Восточно-Китайский педагогический университет, ул. Северный Джонгшан, 3663, 200062 г. Шанхай, Китайская Народная Республика, birs.07@mail.ru, https://orcid.org/0000-0003-4071-0464

Александр Михайлович Барсуков, кандидат политических наук, заместитель декана факультета политики и международных отношений, Сибирский институт управления филиал Российской академии народного хозяйства и государственной службы при Президенте РФ, ул. Нижегородская, 6, 630102 г. Новосибирск, Российская Федерация, amb2@inbox.ru, https://orcid.org/0000-0002-7768-0097 